\title{
The Effect of Maturity Mismatch between Investing and Financing on Audit Pricing*
}

\author{
Hong YIN', Ruo Nan ZHANG ${ }^{2}$
}

Received: June 22, 2020 Revised: July 05, 2020 Accepted: August 10, 2020

\begin{abstract}
This research investigates the consequences of the increase in corporate use of short-term debt in China over the past decades. Using a sample of Chinese firms from 2007 to 2018, we empirically explore the effect of corporate use of short-term debt for long-term investment (SFLI) on audit pricing. We first examine the relationship between SFLI and audit pricing for different groups of firms. Then, we investigate the role of the increase in short-term debt in alleviating principal-agent conflicts and reducing agency costs. We have four primary empirical findings. First, auditors tend to charge SFLI clients higher fees. Second, the negative relationship between SFLI and audit fee is found in private firms, firms audited by Chinese domestic auditors, and firms with higher information asymmetry. Third, the time auditors spent on SFLI clients is significantly more than that spent on non-SFLI clients, suggesting that the decrease in audit fee is not due to the decrease in cost. Fourth, SFLI significantly reduces the agency costs of the firm, which auditors regard as a low risk signal and grant an audit fee discount. Our findings suggest that the decrease in debt maturity, not only influences managerial behaviors, but also influences auditors' risk assessment and pricing decisions.
\end{abstract}

Keywords: Maturity Mismatch, SFLI, Audit Risk, Audit Pricing, Agency Costs

JEL Classification Code: G31, G32, L11, M42

\section{Introduction}

The structure of debt maturity has been a hot topic in corporate finance. The immunization hypothesis holds that long-term assets should be financed with long-term liabilities and equity, while short-term assets should be financed with short-term liabilities. If the funds obtained from short-term financing are used for long-term investment, there will be maturity mismatch (Morris, 1976). The debt maturity mismatch is likely to exert negative impacts,

\footnotetext{
*Acknowledgements:

This paper was funded by Talent Introduction Project of Suzhou Vocational University (No.3180138). The authors would like to thank the Project for their continued interest in this field.

${ }^{1}$ First Author and Corresponding Author. Associate Professor, Department of Accounting, Business College, Suzhou Vocational University, China [Postal Address: No.106 Zhineng Road, Wuzhong District, Suzhou, Jiangsu Province, 215104, China] Email: yinhongcdlg@163.com

2Lecturer, Department of International Trade, Business College, Suzhou Vocational University, China. Email: zhrn3700@163.com

(c) Copyright: The Author(s)

This is an Open Access article distributed under the terms of the Creative Commons Attribution Non-Commercial License (https://creativecommons.org/licenses/by-nc/4.0/) which permits unrestricted non-commercial use, distribution, and reproduction in any medium, provided the original work is properly cited.
onrestricted non-commercial
}

e.g., increasing liquidity risks, frequent renegotiations and financial constraints (Custo'dio, Ferreira, \& Laureano, 2013). The root cause of the debt maturity mismatch is that corporate financing demands cannot be fully met (Acharya, Gale, \& Yorulmazer, 2011). Imperfect financial market and unstable monetary policies lead to insufficient long-term fund supplies. In order to alleviate financing constraints, firms have to use short-term debt for long-term investment. According to the data released by the National Bureau of Statistics of China, the average annual domestic debt for China's total investment in fixed asset from 2015 to 2018 was RMB6.72 trillion. While the average annual increase in medium and long-term bank loans of this period was about RMB4.80 trillion, accounting for only $71.43 \%$ of the average annual domestic debt for China's total investment in fixed asset. It indicates that Chinese firms are probably using short-term loans for long-term investments and the debt maturity mismatch is a common phenomenon in China.

The determinants of debt maturity structure are well documented (Fama \& French, 2001, 2004; Bates, Kahle, \& Stulz, 2009; Nguyen \& Nguyen, 2020). However, the impact of maturity mismatch between investing and financing on audit pricing has rarely been examined. This paper tries to complement the extant literature by examining the impact of 
corporate use of short-term debt for long-term investment on external audit. We posit that the maturity mismatch between corporate investing and financing have two outcomes. First, the maturity mismatch of corporations between investing and financing has an impact on agency costs. Using shortterm loans for long-term investments imposes restrictions on cash assets that are controlled by the management, reduce the self-interest behaviors of the management, alleviate agency conflicts, and avoid over-investment (Jensen \& Meckling, 1976; Richardson, 2006; Denis \& Sibilkov, 2010), leading to reduced audit risk. Second, firms that use short-term loans for long-term investments are signaling to the outside world that they are able to repay debt. Auditors may regard it as a high-quality firm, and assess it as low risk. As a result of the reduced audit risk, auditors are likely to grant the client an audit fee discount.

Our study differs from prior studies in the following ways. First, most prior studies examine the determinants of the maturity mismatch between investing and financing and its impact on corporate financial performance (Goswami, 2000; Mukhibad, Subowo, Maharin, \& Mukhtar, 2020), while this paper explores the impact of maturity mismatch between investing and financing on audit risk and audit fees. Specifically, we find that auditors tend to charge clients with maturity mismatch between investing and financing lower fees. Furthermore, we find that the negative relationship between maturity mismatch and audit fee mainly exists among private firms, firms audited by non-Big-4 auditors and firms with low information transparency.

Second, the results of this research complement extant literature in the field of the determinants of audit fees. Using a sample of over 19,000 firm-year observations, we examine the impact of maturity mismatch on audit pricing from the perspective of the agency theory. The results show that using short-term loans for long-term investments (SFLI) can alleviate the principle-agent conflict and reduce the agency costs. Auditors regard such clients as low-risk firms and grant an audit fee discount. However, auditors have not cut down time in auditing such clients. On the contrary, auditors spend significantly more time in auditing SFLI clients than other clients.

Third, most prior studies focus on the negative consequences of SFLI, while our study indicates that SFLI has certain positive impacts on disciplining managerial behaviors. That may explain why SFLI is so common in China. Meanwhile, our results can deepen the understanding of policymakers, managers and investors in the economic consequences of the maturity mismatch between investing and financing. The remainder of this research is organized as follows. Section 2 reviews the prior literature, develops the theoretical framework and presents the hypothesis. Section 3 presents the research design. Section 4 reports the descriptive statistics and regression results. Section 5 offers concluding comments.

\section{Theoretical Framework}

The great achievements of China's economy since the reform and opening up are attributed to the drive of investment, consumption and export, among which investment is of the utmost importance. The average annual growth rate of fixed asset investment in China has been high. However, the proportion of medium and long-term bank loans has been declining in recent years.

The debt maturity mismatch has aroused the extensive attention of scholars and practitioners. Corporate use of short-term loans for long-term investment may increase the exposure of firms to liquidity risks. As prior studies show, the debt maturity mismatch is one of the causes of 20072008 financial crisis (Almeida, Campello, Laranjeira, \& Weisbenner, 2012). However, due to information asymmetry and instable monetary policies in China, it is difficult for banks to form stable expectations, so banks are lack of enthusiasm in granting long-term loans. Compared to long-term loans, short-term loans are more flexible. When a short-term loan is due, the firm can negotiate with the bank and renew the loan, putting its financial risks at control. Therefore, many Chinese firms, especially private firms, choose to use shortterm debt rather long-term debt as well as capital to finance the long-term investment. To some extent, SFLI alleviates the underinvestment of high growth firms (Myers, 1977).

Audit risk is a key factor in audit pricing (Abbott, Gunny, \& Pollard, 2017). Simunic (1980) documents that auditors tend to charge clients with high litigation risk higher audit fees. Seetharaman, Gul, \& Lynn (2002) further documents that whether auditors charge clients with high litigation risk higher audit fees is contingent upon the legal environment of the host country. Legal systems in China lag rather behind and the legal enforcement is poor. Auditors face low litigation risk. Meanwhile, the audit market in China is highly competitive. Auditors may not charge high-risk clients significantly high audit fees in case of loss of clients. As corporate use of shortterm debt for long-term investment can affect auditor's risk evaluation, will it affect audit pricing? This is an interesting problem that remains to be tested by empirical evidence.

SFLI may affect auditor's risk evaluation and audit fees in the following ways. First, SFLI is based on the management's confidence in coping with future liquidity risk. The choice of SFLI often indicates that managers feel confident about the future operation of the firm. It signals to the market that it is a high-quality firm (Campello, Giambona, Graham, \& Harvey, 2011; Flannery, 1986). The business risk of a promising firm is usually low. Auditors tend to evaluate such firms as lowrisk clients, and grant an audit fee discount. Hence, audit fees may be expected to be negatively related with SFLI.

Second, according to agency theory, SFLI helps reduce the agency costs. Due to the short repayment period of short-term debt, the free cash flow controlled by managers is less. It can 
help alleviate the moral hazard of managers (Jensen, 1986), and reduce over-investment (Myers, 1977). Banks will also enhance supervision on firms with high proportion of shortterm debts from the perspective of risk aversion. Ho and Singer (1982) documents that the higher the proportion of short-term debt, the more effective the supervision on shareholders and managers. Lower agency costs bring lower litigation risk and regulatory risk. Thus, auditors are likely to charge such clients lower audit fees. Therefore, we predict a negative relationship between the degree of SFLI and audit fees.

Third, when a short-term debt is due, the firm has to borrow new debt to repay old ones, so financial risk increases. According to audit insurance demand hypothesis, external audit is a financial statement risk transfer mechanism. The value of audit lies mainly in assurance and insurance, i.e., to ensure the reliability of information. SFLI clients face higher risks of lawsuits in the future. In order to avoid future lawsuits, auditors will increase audit fees for SFLI clients as compensation. Meanwhile, SFLI clients are more likely to carry out earnings management in order to obtain new bank loans to repay old ones. Their accounting information quality may be poor. Auditors have to spend more time in substantive procedures, causing the increase in audit costs. In order to make up for the rising cost, auditors may increase audit fees for SFLI clients. Therefore, we predict a positive relationship between the degree of SFLI and audit fees. Considering the interaction of the above two different forces, we present the following alternative hypotheses:

H1a: Ceteris paribus, the degree of corporate use of short-term debt for long-term investment is significantly positive with audit fees.

H1b: Ceteris paribus, the degree of corporate use of short-term debt for long-term investment is significantly negative with audit fees.

\section{Research Design}

\subsection{Sample Selection and Data Source}

We draw our sample of Chinese firms from China Stock Market \& Accounting Research Database (CSMAR). The sample period ranges from 2007 to 2018 . We begin our sample in 2007 because China began to implement new accounting standards and auditing standards in 2007 . We exclude financial firms as these firms tend to have different capital structures. We drop any industry in which there are less than 10 listed firms. We then drop any observation with missing financial data. The final sample has a total of 19865 observations.

\subsection{Model Design}

For our empirical test, we use the following measure of SFLI drawn on prior research:
SFLI $=$ [cash paid for acquisition and construction of fixed assets, intangible assets and other long-term assets (change of long-term debts + change of owner's equity + net cash flow from operating activities - net cash flow from disposal of fixed assets, intangible assets and other longterm assets)] / the beginning total assets

We take the natural logarithm of the audit fee (LNFEE) as the dependent variable and regress it on SFLI to analyze the effect of a client's debt maturity mismatch on the audit fee. Following prior studies (Sinumic, 1980), we estimate the following regression to test $\mathrm{H} 1 \mathrm{a}$ and $\mathrm{H} 1 \mathrm{~b}$ :

$$
\begin{aligned}
\text { LNFEE }_{i, t}= & \beta_{0}+\beta_{1} \text { SFLI }_{i, t}+\beta_{2} \text { SIZE }_{i, t}+\beta_{3} \text { LEV }_{i, t} \\
& +\beta_{4} \text { ROA }_{i, t}+\beta_{5} \text { SOE }_{i, t}+\beta_{6} \text { TOP }_{i, t} \\
& +\beta_{7} \text { BM }_{i, t}+\beta_{8} \text { REC }_{i, t}+\beta_{9} \text { INVENTORY }_{i, t} \\
& +\beta_{10} \text { CURRENT }_{i, t}+\beta_{11} \text { LOSS }_{i, t} \\
& +\beta_{12} \text { OPINION }_{i, t}+\beta_{13} \text { BIG }_{i, t} \\
& +\beta_{14} \text { LOCATE }_{i, t}+\text { YEAR } \\
& + \text { INDUSTRY } \varepsilon
\end{aligned}
$$

The variable SFLI is our test variable, and the predicted sign in the regression is the focus of this research. We include the following variables to control for the size effect, audit complexity and risk of the engagement (Ng \& Tai, 1994; Higgs \& Skantz, 2006; Choi, Kim, \& Zang, 2010; Asthana \& Kalelkar, 2014): SIZE (natural logarithm of total assets of the client), LEV (total debt scaled by total assets), ROA (net income scaled by total assets), SOE (an indicator variable equal to 1 if the client is state-owned, and 0 otherwise), TOP1 (proportion of the largest shareholder), BM (the book-to-market ratio as a proxy for growth expectation), REC (receivables scaled by total assets), INVENTORY (inventory scaled by total assets), CURRENT (current assets divided by current liabilities), LOSS (an indicator variable that takes a value of 1 if the client reports a loss, and 0 otherwise), OPINION (an indicator variable that takes a value of 1 if the client receives a qualified audit opinion, and 0 otherwise), BIG4 (an indicator variable equal to 1 if the client is audited by Big 4, and 0 otherwise). Due to the vast territory of China, the development of economy and legal systems vary dramatically, resulting in great differences in legal risks between regions. Therefore, we include LOCATE (an indicator variable that takes a value of 1 if the office of the client is located in Beijing, Shanghai, Guangdong, Tianjin, Chongqing, Zhejiang, Jiangsu, and 0 otherwise) to control for the effect of legal risk. YEAR and INDUSTRY variables are included in the model to control for time-specific and industry-specific effects. 
Table 1: Variable Definitions

\begin{tabular}{|c|c|c|}
\hline Type & Variable & Definition \\
\hline \multirow{5}{*}{ Main Variables } & LNFEE & natural logarithm of the audit fee \\
\hline & SFLI & $\begin{array}{l}\text { [cash paid for acquisition and construction of fixed assets, intangible assets and other } \\
\text { long-term assets - (change of long-term debts + change of owner's equity + net cash } \\
\text { flow from operating activities - net cash flow from disposal of fixed assets, intangible } \\
\text { assets and other long-term assets)] / the beginning total assets }\end{array}$ \\
\hline & Dum_SFLI & an indicator variable equal to 1 if SFLI > 0 , and 0 otherwise. \\
\hline & AUDITLAG & natural logarithm of days between balance sheet date and audit report date \\
\hline & $A C$ & $\begin{array}{l}\text { Agency costs calculated as the sales expense plus overhead divided by operating } \\
\text { revenue }\end{array}$ \\
\hline \multirow{14}{*}{ Control variables } & SIZE & natural logarithm of total assets \\
\hline & LEV & total liabilities / total assets \\
\hline & ROA & net profit / average total assets \\
\hline & SOE & an indicator variable equal to 1 if the client is state-owned, and 0 otherwise \\
\hline & TOP1 & proportion of the largest shareholder \\
\hline & BM & book-to-market ratio \\
\hline & REC & receivables / total assets \\
\hline & INVENTORY & inventory / total assets \\
\hline & CURRENT & current assets / current liabilities \\
\hline & LOSS & a dichotomous variable with value of 1 if the client reports a loss, and 0 otherwise \\
\hline & OPINION & $\begin{array}{l}\text { an indicator variable that takes a value of } 1 \text { if the client receives a qualified audit } \\
\text { opinion, and } 0 \text { otherwise }\end{array}$ \\
\hline & BIG4 & a dummy variable equal to 1 if the client is audited by Big 4 , and 0 otherwise \\
\hline & LOCATE & $\begin{array}{l}\text { a dummy variable that takes a value of } 1 \text { if the office of the client is located in Beijing, } \\
\text { Shanghai, Guangdong, Tianjin, Chongqing, Zhejiang, Jiangsu, and } 0 \text { otherwise) }\end{array}$ \\
\hline & DA & $\begin{array}{l}\text { discretionary accruals calculated using the cross-sectional modified version of the } \\
\text { Jones model (Jones, 1991; Dechow, Sloan, \& Sweeney, 1995), deflated by total assets } \\
\text { and estimated by year and for each industry }\end{array}$ \\
\hline
\end{tabular}

\section{Empirical Results}

\subsection{Descriptive Statistics}

Table 2 reports the sample mean, standard deviation, minimum, maximum, median, and the first and third quartiles of main variables. About one third of the clients use short-term debt for long-term investment, which indicates that SFLI is a common phenomenon in China. About 10 percent of the clients report a loss. Only 5.3\% of the sample firms is audited by Big 4 auditors, much fewer than those in developed capital market. Then, we calculate the Pearson and Spearman correlations for main variables.
Our variable of interest SFLI is negatively correlated with LNFEE, which indicates that auditors tend to charge SFLI clients higher audit fees. SIZE, LEV, SOE, TOP1, BM, INVENTORY, CURRENT, LOCATE are all positively correlated with LNFEE, which indicates that auditors tend to charge large clients, highly leveraged clients, state-owned clients, clients with high risks and complex operations higher audit fees. The correlations between BIG 4 and LNFEE are significantly positive, indicating that Big 4 auditors tend to charge significantly more than Chinese domestic auditors. LOCATE is positively related with LNFEE, suggesting that auditors are likely to charge more in high litigation risk regions. 
Table 2: Descriptive Statistics

\begin{tabular}{|l|c|c|c|c|c|c|c|c|}
\hline Variable & $\mathbf{N}$ & Mean & Std & Min & p25 & Median & p75 & Max \\
\hline LNFEE & 19865 & 13.520 & 0.660 & 12.250 & 13.080 & 13.430 & 13.860 & 15.750 \\
\hline SFLI & 19865 & -0.107 & 0.328 & -2.379 & -0.142 & -0.046 & 0.029 & 0.352 \\
\hline DUM_SFLI & 19865 & 0.336 & 0.472 & 0.000 & 0.000 & 0.000 & 1.000 & 1.000 \\
\hline SIZE & 19865 & 22.090 & 1.313 & 19.080 & 21.150 & 21.930 & 22.870 & 25.890 \\
\hline LEV & 19865 & 0.477 & 0.218 & 0.052 & 0.313 & 0.481 & 0.634 & 1.172 \\
\hline ROA & 19865 & 0.039 & 0.063 & -0.231 & 0.012 & 0.035 & 0.067 & 0.241 \\
\hline SOE & 19865 & 0.463 & 0.499 & 0.000 & 0.000 & 0.000 & 1.000 & 1.000 \\
\hline TOP1 & 19865 & 35.360 & 15.210 & 8.790 & 23.200 & 33.340 & 45.970 & 74.980 \\
\hline BM & 19865 & 0.613 & 0.246 & 0.102 & 0.423 & 0.616 & 0.807 & 1.114 \\
\hline REC & 19865 & 0.105 & 0.098 & 0.000 & 0.025 & 0.079 & 0.156 & 0.446 \\
\hline INVENTORY & 19865 & 0.164 & 0.155 & 0.000 & 0.063 & 0.123 & 0.208 & 0.755 \\
\hline CURRENT & 19865 & 0.859 & 0.730 & 0.062 & 0.449 & 0.700 & 1.004 & 5.169 \\
\hline LOSS & 19865 & 0.106 & 0.307 & 0.000 & 0.000 & 0.000 & 0.000 & 1.000 \\
\hline OPINION & 19865 & 0.041 & 0.198 & 0.000 & 0.000 & 0.000 & 0.000 & 1.000 \\
\hline BIG4 & 19865 & 0.053 & 0.223 & 0.000 & 0.000 & 0.000 & 0.000 & 1.000 \\
\hline LOCATE & 19865 & 0.543 & 0.498 & 0.000 & 0.000 & 1.000 & 1.000 & 1.000 \\
\hline
\end{tabular}

Table 3: Multivariate Regression Analysis

\begin{tabular}{|c|c|c|c|c|c|c|}
\hline & \multicolumn{2}{|c|}{ Full Sample } & \multicolumn{2}{|c|}{ Private Firms } & \multicolumn{2}{|c|}{ State-Owned Firms } \\
\hline & Coeff. & T-value & Coeff. & T-value & Coeff. & T-value \\
\hline SFLI & $-0.0245^{\star * *}$ & -2.68 & $-0.0449^{* * *}$ & -4.30 & -0.0001 & -0.01 \\
\hline SIZE & $0.3712^{* * *}$ & -106.51 & $0.3351^{* \star *}$ & -72.14 & $0.4078^{* * *}$ & -75.99 \\
\hline LEV & $0.1248^{* * *}$ & -6.00 & $0.1118^{* * *}$ & -3.90 & $0.1455^{\star * *}$ & -4.54 \\
\hline ROA & $-0.3693^{* * *}$ & -5.44 & $-0.2774^{* * *}$ & -3.38 & $-0.5057^{\star \star *}$ & -4.38 \\
\hline SOE & $-0.1113^{* * *}$ & -17.79 & & & & \\
\hline TOP1 & $-0.0010^{* * *}$ & -4.93 & -0.0002 & -0.91 & $-0.0021^{* * *}$ & -7.08 \\
\hline $\mathrm{BM}$ & $-0.2244^{* * *}$ & -12.92 & $-0.2062^{* * *}$ & -9.17 & $-0.2493^{\star * *}$ & -9.02 \\
\hline REC & $0.1324^{* * *}$ & -3.87 & $0.1821^{* \star *}$ & -4.39 & 0.0947 & -1.64 \\
\hline INVENTORY & $-0.1224^{* \star *}$ & -4.65 & -0.0498 & -1.46 & $-0.1609^{* * *}$ & -3.94 \\
\hline CURRENT & $-0.0154^{* * *}$ & -2.77 & 0.0079 & -0.87 & $-0.0354^{* * *}$ & -4.84 \\
\hline LOSS & $0.0230^{*}$ & -1.94 & $0.0388^{\star \star}$ & -2.42 & 0.0057 & -0.32 \\
\hline OPINION & $0.1190^{* * *}$ & -7.79 & $0.1037^{* * *}$ & -5.52 & $0.1259^{* * *}$ & -5.02 \\
\hline BIG4 & $0.5886^{* * *}$ & -45.01 & $0.5762^{* * *}$ & -27.83 & $0.5752^{* * *}$ & -33.18 \\
\hline LOCATE & $0.1606^{* * *}$ & -27.71 & $0.1364^{* * *}$ & -18.51 & $0.1785^{* * *}$ & -19.27 \\
\hline Intercept & $5.3421^{* \star *}$ & -76.13 & $5.9784^{* * *}$ & -62.46 & $4.5825^{* * *}$ & -42.82 \\
\hline Industry dummies & \multicolumn{2}{|c|}{ Yes } & \multicolumn{2}{|c|}{ Yes } & \multicolumn{2}{|c|}{ Yes } \\
\hline Year dummies & \multicolumn{2}{|c|}{ Yes } & \multicolumn{2}{|c|}{ Yes } & \multicolumn{2}{|c|}{ Yes } \\
\hline $\mathrm{N}$ & \multicolumn{2}{|c|}{19865} & \multicolumn{2}{|c|}{10675} & \multicolumn{2}{|c|}{9190} \\
\hline Adj.R2 & \multicolumn{2}{|c|}{0.665} & \multicolumn{2}{|c|}{0.635} & \multicolumn{2}{|c|}{0.694} \\
\hline F-value & \multicolumn{2}{|c|}{917.15} & \multicolumn{2}{|c|}{443.96} & \multicolumn{2}{|c|}{496.11} \\
\hline P-value & \multicolumn{2}{|c|}{$<0.001$} & \multicolumn{2}{|c|}{$<0.001$} & \multicolumn{2}{|c|}{$<0.001$} \\
\hline
\end{tabular}

Note: ${ }^{* * *},{ }^{* *},{ }^{*}$ denote two-tailed significance at the 1 percent, 5 percent, and 10 percent level, respectively. Figures in parentheses are T-values. 


\subsection{Regression Results}

In Table 3, we present the results of multivariate analyses. The audit fee regression for the full sample is reported in Table 3. The model is significant with $\mathrm{p}$ value $<0.001$. The adjusted R-Square is 0.665 . The coefficient of SFLI is -0.0245 and is significant at the less than 1 percent level, proving Hypothesis H1b. Of the client-level control variables, SIZE, LEV, REC, LOSS, OPINION are positive, and ROA, SOE, TOP1, BM, INVENTORY, CURRENT are negative. BIG4 is positive and significant at the 1 percent level. LOCATE is positive and significant at the 1 percent level or better, indicating that auditors tend to charge higher fees in regions with more investor protection and higher litigation risk.

The nature of property right and political connection of the client may have an impact on banks' lending decision (Khwaja \& Mian, 2005; Faccio, 2006). In China, due to the natural connection between state-owned enterprises and state-owned banks, state-owned enterprises can get bank loans more easily than private firms (Ladd, 1998; Loury, 1998). The government's invisible guarantee weakens the bank's supervision motivation. Therefore, differences may exist between state-owned enterprises and private firms in the relationship between SFLI and audit pricing. Thus, we run the model by partitioning the sample into two subsamples according to whether the firm is state-owned or private. We find a significant and negative correlation between SFLI and audit fee in private firms, but not in state-owned enterprises. This may be due to the fact that private firms are at a disadvantage when applying for bank loans. They are often regarded by banks as high-risk clients. If private firms use short-term loans for long-term investment, banks will probably raise risk rating and enhance supervision. Thus, the agency costs of private firms will decline. And auditors will grant an audit fee discount.

As audit quality is difficult to observe, the market often takes auditor brand and size as the substitute for audit quality (Chae, Nakano, \& Fujitani, 2020). Auditors with recognized brand or large in size are often regarded as of high-quality (Francis, 1984). As for audit demand, listed firms are willing to engage auditors with well-known brands and pay high audit fees so as to improve their corporate images. As for audit supply, audit fee depends not only on the audit risk observed by the auditor, but also on the relative negotiation ability of the auditor (Abbott, Parker, Peters, \& Rama, 2003). Big4 auditors have highly recognized brands, reputation, and relatively strong negotiation abilities. They may be unwilling to charge SFLI clients lower fees. In order to test whether differences exist between Big 4 and non-big4 auditors in the relationship between SFLI and audit fee, we run the model by partitioning the sample into two subsamples according to whether the firm is audited by Big 4 auditors or not. The regression results are shown in Column (1) - Column (4) of Table 4. The domestic auditors (Big4 auditors) regression has an adjusted $\mathrm{R}^{2}$ of 0.597
(0.619) with a p-value of less than 0.001. The coefficient of SFLI is significantly negative in the regression for Non-Big4, suggesting that Chinese domestic auditors tend to charge lower fees towards SFLI clients. While the coefficient of SFLI is insignificant in the regression for Big4, indicating that Big 4 auditors do not charge SFLI clients higher fees.

Improving information transparency can help alleviate the information asymmetry between managers and shareholders, enhance the supervision on managers, reduce the likelihood of moral hazard of the management, and reduce agency costs (Baimukhamedova, Baimukhamedova, \& Luchaninova, 2017). The principal-agent problem of firms with poor information transparency is always more serious. When they use short-term debt for long-term investment, the supervision and governance of banks would be more obvious. Therefore, we expect that the negative impact of SFLI on audit pricing will be more significant in poor information transparency group. We measure information transparency by discretionary accruals. We define DA as discretionary accruals calculated using the cross-sectional modified version of the Jones model (Jones, 1991; Dechow, Sloan, \& Sweeney 1995), deflated by total assets and estimated by year and for each industry. If a firm's DA exceeds the year-industry median, it is defined as Low Information Transparency. Otherwise, it is defined as High Information Transparency. The regression results are presented in Column (5) - Column (8) of Table 4. As can be seen from the table, the coefficient on SFLI for Low Transparency group is -0.0264 and is significant at the 5 percent level. However, the coefficient on SFLI for High Transparency group is insignificant, suggesting that information environment does have an effect on the relationship between SFLI and audit fees.

\subsection{Sensitivity Analysis}

We conduct several sensitivity tests to confirm the robustness of our results.

1. We use alternate definition for the independent variable. We set a dichotomous variable DUM_SFLI that has a value of 1 if the firm uses short-term debt for long-term investment, and 0 otherwise. In Column (1) of Table 5, DUM_SFLI is significantly negative at the $1 \%$ level with a value of -0.0171 $(\mathrm{t}=-2.65)$. Our inferences remain unchanged.

2. Next, we repeat the test with the dependent variable defined as audit fee adjusted by total assets (AUDITFEE). In Column (2) of Table 5, SFLI is significantly negative at the $1 \%$ level with a value of $-0.0003(\mathrm{t}=-3.83)$. Once again, our inferences remain unchanged.

3. To eliminate the standard errors at the firm level and improve the accuracy of the estimation, we re-run the test by clustering the standard errors at the firm level. The results continue to hold. In Column (3) of Table 5, the coefficient of SFLI is -0.0245 and is significant at the $5 \%$ level. 
Table 4: Regression by Group of Firms

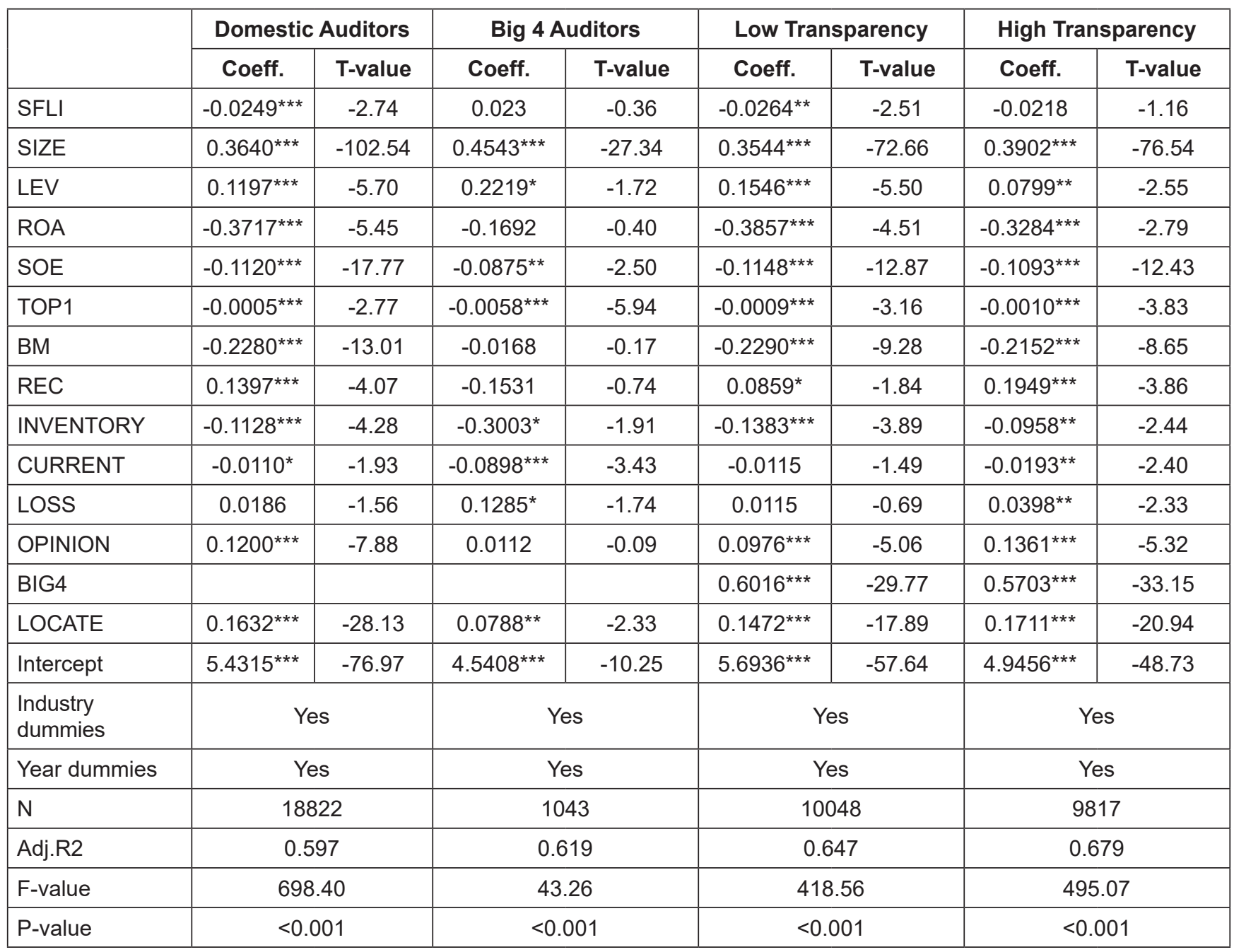

Note: ${ }^{* * *},{ }^{* *},{ }^{*}$ denote two-tailed significance at the 1 percent, 5 percent, and 10 percent level, respectively. Figures in parentheses are T-values.

\subsection{Further Discussion}

\subsubsection{SFLI, Audit Delay and Audit Pricing}

Audit cost is an important consideration in audit pricing. The negative relationship between SFLI and audit fee may result from the reduced agency costs of clients and low risk assessment of auditors (audit risk hypothesis). Or it may result from the reduced time and scope of substantive tests in the audit process. The audit costs decrease, causing the decline of audit fees (audit cost hypothesis). To explore the potential effect of audit cost on audit fee, we introduce two variables AUDITLAG (audit delay) and AC (agency costs) into the model to investigate the mediating role of audit cost and audit risk. We use the method of step-by-step regression to test the mediating role of audit cost between SFL and audit fee. We estimate the following regressions:

$$
\begin{aligned}
& A U D I T L A G_{i, t}=\alpha_{0}+\alpha_{1} S F L I_{i, t}+\alpha_{2} S I Z E_{i, t} \\
& +\alpha_{3} L E V_{i, t}+\alpha_{4} R O A_{i, t} \\
& +\alpha_{5} S O E_{i, t}+\alpha_{6} T O P 1_{i, t} \\
& +\alpha_{7} B M_{i, t}+\alpha_{8} R E C_{i, t} \\
& +\alpha_{9} \text { INVENTORY } Y_{i, t} \\
& +\alpha_{10} \text { CURRENT }_{i, t}+\alpha_{11} \text { LOSS }_{i, t} \\
& +\alpha_{12} \text { OPINION }_{i, t}+\alpha_{13} \text { BIG }_{i, t} \\
& +\alpha_{14} L_{O C A T E}+Y E A R \\
& + \text { INDUSTRY }+\varepsilon
\end{aligned}
$$


Table 5: Sensitivity Analysis

\begin{tabular}{|c|c|c|c|c|c|c|}
\hline & \multicolumn{2}{|c|}{ (1) } & \multicolumn{2}{|c|}{ (2) } & \multicolumn{2}{|c|}{ (3) } \\
\hline & Coeff. & T-value & Coeff. & T-value & Coeff. & T-value \\
\hline SFLI & $-0.0171^{* * *}$ & -2.65 & $-0.0003^{\star * *}$ & -3.83 & $-0.0245^{\star *}$ & -2.16 \\
\hline SIZE & $0.3705^{\star \star *}$ & -106.13 & $-0.0044^{* * *}$ & -141.17 & $0.3712^{* \star *}$ & -40.69 \\
\hline LEV & $0.1261^{* * *}$ & $\begin{array}{l}-6.06 \\
\end{array}$ & $0.0016^{* * *}$ & -8.73 & $0.1248^{* * *}$ & -2.89 \\
\hline ROA & $-0.3525^{\star \star *}$ & -5.32 & $-0.0046^{* \star *}$ & -7.57 & $-0.3693^{* * *}$ & -3.39 \\
\hline SOE & $-0.1124^{* * *}$ & -17.96 & $-0.0010^{* * *}$ & -17.23 & $-0.1113^{* * *}$ & -7.33 \\
\hline TOP1 & $-0.0009^{* * *}$ & -4.88 & 0.0000 & -0.9 & $-0.0010^{* *}$ & -2.07 \\
\hline BM & $-0.2185^{\star * *}$ & -12.61 & $-0.0028^{* * *}$ & -18.42 & $-0.2244^{* * *}$ & -6.43 \\
\hline REC & $0.1301^{* * *}$ & -3.81 & $-0.0007^{* *}$ & -2.33 & $0.1324^{*}$ & -1.84 \\
\hline INVENTORY & $-0.1237^{* * *}$ & -4.7 & $-0.0015^{* * *}$ & -6.46 & $-0.1224^{* *}$ & -2.22 \\
\hline CURRENT & $-0.0156^{* * *}$ & -2.8 & $0.0001^{* *}$ & -1.97 & -0.0154 & -1.32 \\
\hline LOSS & $0.0285^{\star *}$ & -2.39 & 0.0002 & -1.47 & 0.023 & -1.54 \\
\hline OPINION & $0.1202^{* * *}$ & -7.88 & $0.0022^{* * *}$ & -16.25 & $0.1190^{* * *}$ & -5.39 \\
\hline BIG4 & $0.5871^{* * *}$ & -44.91 & $0.0046^{* * *}$ & -39.5 & $0.5886^{* * *}$ & -14.75 \\
\hline LOCATE & $0.1606^{* * *}$ & -27.72 & $0.0012^{* * *}$ & -22.83 & $0.1606^{\star * *}$ & -11.11 \\
\hline Intercept & $5.3624^{* * *}$ & -76.11 & $0.1111^{* * *}$ & -178.23 & $5.3421^{* * *}$ & -29.82 \\
\hline Industry dummies & \multicolumn{2}{|c|}{ Yes } & \multicolumn{2}{|c|}{ Yes } & \multicolumn{2}{|c|}{ Yes } \\
\hline Year dummies & \multicolumn{2}{|c|}{ Yes } & \multicolumn{2}{|c|}{ Yes } & \multicolumn{2}{|c|}{ Yes } \\
\hline $\mathrm{N}$ & \multicolumn{2}{|c|}{19865} & \multicolumn{2}{|c|}{19865} & \multicolumn{2}{|c|}{19865} \\
\hline Adj.R2 & \multicolumn{2}{|c|}{0.666} & \multicolumn{2}{|c|}{0.754} & \multicolumn{2}{|c|}{0.666} \\
\hline F-value & \multicolumn{2}{|c|}{917.14} & \multicolumn{2}{|c|}{1414.27} & \multicolumn{2}{|c|}{190.22} \\
\hline P-value & \multicolumn{2}{|c|}{$<0.001$} & \multicolumn{2}{|c|}{$<0.001$} & \multicolumn{2}{|c|}{$<0.001$} \\
\hline
\end{tabular}

Note: ${ }^{* * *},{ }^{* *},{ }^{*}$ denote two-tailed significance at the 1 percent, 5 percent, and 10 percent level, respectively. Figures in parentheses are T-values.

Table 6: SFLI, Audit Delay and Audit Fee

\begin{tabular}{|c|c|c|c|c|c|c|}
\hline & (1) & (2) & (3) & (4) & (5) & (6) \\
\hline & D.V.=LNFEE & D.V.=AUDITLAG & D.V.=LNFEE & D.V.=LNFEE & D.V. $=A C$ & D.V.=LNFEE \\
\hline \multirow{2}{*}{ SFLI } & $-0.0245^{\star * *}$ & $0.0276^{* * *}$ & $-0.0270^{* * *}$ & $-0.0245^{\star \star *}$ & $-0.0102^{* * *}$ & $-0.0217^{* *}$ \\
\hline & $(-2.68)$ & $(4.53)$ & $(-2.96)$ & $(-2.68)$ & $(-3.53)$ & $(-2.39)$ \\
\hline \multirow{2}{*}{ AUDITLAG/AC } & & & $0.0905^{* * *}$ & & & $0.2418^{\star * *}$ \\
\hline & & & $(8.52)$ & & & $(10.58)$ \\
\hline \multirow{2}{*}{ Intercept } & $5.3421^{* * *}$ & $4.0779^{* * *}$ & $4.9731^{* \star *}$ & $5.3421^{* * *}$ & $0.8244^{* * *}$ & $5.2110^{\star \star \star}$ \\
\hline & $(76.13)$ & $(87.05)$ & $(60.39)$ & $(76.13)$ & $(42.66)$ & $(73.33)$ \\
\hline Control Variables & Yes & Yes & Yes & Yes & Yes & Yes \\
\hline Industry dummies & Yes & Yes & Yes & Yes & Yes & Yes \\
\hline Year dummies & Yes & Yes & Yes & Yes & Yes & Yes \\
\hline $\mathrm{N}$ & 19865 & 19865 & 19865 & 19865 & 19865 & 19865 \\
\hline Adj.R2 & 0.665 & 0.0854 & 0.666 & 0.665 & 0.256 & 0.667 \\
\hline F-value & 917.15 & 44.16 & 901.19 & 917.15 & 185.40 & 903.86 \\
\hline P-value & $<0.001$ & $<0.001$ & $<0.001$ & $<0.001$ & $<0.001$ & $<0.001$ \\
\hline
\end{tabular}

Note: ${ }^{* * *},{ }^{* *},{ }^{*}$ denote two-tailed significance at the 1 percent, 5 percent, and 10 percent level, respectively. Figures in parentheses are T-values. 


$$
\begin{aligned}
\text { LNFEE }_{i, t}= & \gamma_{0}+\gamma_{1} \text { SFLI }_{i, t}+\gamma_{2} \text { AUDITLAG }_{i, t} \\
& +\gamma_{3} \text { SIZE }_{i, t}+\gamma_{4} \text { LEV }_{i, t}+\gamma_{5} \text { ROA }_{i, t} \\
& +\gamma_{6} \text { SOE }_{i, t}+\gamma_{7} \text { TOP }_{i, t}+\gamma_{8} \text { BM }_{i, t} \\
& +\gamma_{9} \text { REC }_{i, t}+\gamma_{10} \text { INVENTORY }_{i, t} \\
& +\gamma_{11} \text { CURRENT }_{i, t}+\gamma_{12} \text { LOSS }_{i, t} \\
& +\gamma_{13} \text { OPINION }_{i, t}+\gamma_{14} \text { BIG }_{i, t} \\
& +\gamma_{15} \text { LOCATE }_{i, t}+\text { YEAR } \\
& + \text { INDUSTR }+\varepsilon
\end{aligned}
$$

AUDITLAG, which is used to measure audit cost, is the natural logarithm of days between balance sheet date and audit report date. If the audit cost hypothesis holds, the sign of the coefficient of SFLI in Model (3) is expected to be negative. The regression result is presented in Column (1) - Column (3) of Table 6. As can be seen from the table, the coefficient of SFLI is 0.0276 and is significant at the 1 percent level, suggesting that auditors have not reduced the time and input for SFLI clients. On the contrary, the time spent on SFLI clients is significantly more than that spent on non-SFLI clients. In Column (3) of Table 6, we report the results for Model (4). The coefficient of SFLI is -0.0270 , significant at the 1 percent level. And the coefficient of AUDITLAG is 0.0905 , significant at the $1 \%$ level. The results suggest that auditors charge SFLI clients less fees not because of the reduced costs but because of the low risks.

\subsubsection{SFLI, Agency Costs and Audit Fee}

In order to test the mediating role of agency costs in the relationship between SFLI and audit price, we construct the following models:

$$
\begin{aligned}
A C_{i, t}= & \alpha_{0}+\alpha_{1} S F L I+\alpha_{2} S_{Z I E E_{i, t}}+\alpha_{3} L E V_{i, t} \\
& +\alpha_{4} \text { ROA }_{i, t}+\alpha_{5} S O E_{i, t}+\alpha_{6} T O P 1_{i, t} \\
& +\alpha_{7} \text { LOSS }_{i, t}+\alpha_{8} B I G 4_{i, t}+Y E A R \\
& +I N D U S T R Y+\varepsilon
\end{aligned}
$$

$$
\begin{aligned}
\text { LNFEE }_{i, t}= & \gamma_{0}+\gamma_{1} \text { SFLI }_{i, t}+\gamma_{2} A_{C_{i, t}}+\gamma_{3} \text { SIZE }_{i, t} \\
& +\gamma_{4} \text { LEV }_{i, t}+\gamma_{5} \text { ROA }_{i, t}+\gamma_{6} \text { SOE }_{i, t} \\
& +\gamma_{7} \text { TOP }_{i, t}+\gamma_{8} \text { BM }_{i, t}+\gamma_{9} \text { REC }_{i, t} \\
& +\gamma_{10} \text { INVENTORY }_{i, t}+\gamma_{11} \text { Current }_{i, t} \\
& +\gamma_{12} \text { LOSS }_{i, t}+\gamma_{13} \text { OPINION }_{i, t} \\
& +\gamma_{14} \text { BIG4 }_{i, t}+\gamma_{15} \text { LOCATE }_{i, t}+\text { YEAR } \\
& + \text { INDUSTRY }+\varepsilon
\end{aligned}
$$

$\mathrm{AC}$, which measures agency costs, is the sales expense plus overhead divided by operating revenue. The regression results are presented in Column (4) - Column (6) of Table 6. The coefficient of SFLI in model (5) is expected to be significantly negative. The coefficient of AC in Model (6) is expected to be significantly positive. As is shown in Table 6, the coefficient of SFLI in Model (5) is -0.0102, significant at the $1 \%$ level. The coefficient of AC in Model (6) is 0.2418 , significant at the $1 \%$ level. And the coefficient of SFLI in Model (6) is -0.0217 , significant at the $5 \%$ level. Thus, the mediating effect of agency costs holds. That is to say, SFLI clients tend to have reduced agency costs. Auditors regard SFLI clients as low-risk and grant fee discounts.

\section{Conclusions}

SFLI is an alternative financing in the context of financial repression. SFLI increases the pay-off pressure of firms and aggravate the risks in going concern. On the other hand, it provides financial support for corporate investment through short-term debt with relatively low interest rate, alleviates financing constraints and reduces financing cost. Meanwhile, the use of short-term debt for long-term investment reduces the free cash flow at the disposal of the management, eases the principal-agent conflict and decreases the agency costs. The modern risk-oriented audit requires auditors to identify and evaluate the risk of material misstatement of the client. So, will auditors consider the impact of SFLI on corporate risk and earnings when making pricing decisions? This is a question this paper attempts to answer.

Using a sample of Chinese A-share firms listed in Shanghai and Shenzhen Stock Exchanges, this paper empirically investigates the impact of corporate maturity mismatch on audit pricing. Results show that auditors tend to charge lower audit fees for SFLI clients. But the negative relationship between SFLI and audit fee only exists in private firms, firms audited by Chinese domestic auditors other than Big 4, firms with low information transparency. Further research indicates that the time auditors spend on SFLI clients is significantly more than that spent on nonSFLI clients. The reason why auditors charge SFLI clients less is that the agency costs of SFLI clients tend to be fewer and auditors are likely to take them as low-risk clients.

The findings of this research have the following implications. First, as an alternative financing, SFLI always has a negative impact on corporate financial performance and risks, but it can weaken the control of managers over corporate resources and alleviate the principal-agent conflict. Therefore, for listed firms, more importance should be attached to the role of debt financing in corporate governance. When the bankruptcy risk of a firm is low, short-term debts can be introduced appropriately. It is an effective way to restrain the equity agency problem by creditor governance. 
A power-balancing governance structure should be set up. For highly leveraged firms, information disclosure should be enhanced. And the role of external audit in corporate governance should be given to full play, which can signal to the market that its accounting information is of high-quality.

Second, the findings of this paper have important reference value for policymakers. In recent years, SASAC (the State-Owned Assets Supervision and Administration Commission) of China's State Council has carried out a series of deleveraging measures. The leverage of both stateowned enterprises and private enterprises has been declining. Deleveraging is conducive to reducing the financial risk and bankruptcy risk of enterprises, but it inevitably weakens the supervision of creditors and deteriorates insider control. Therefore, policymakers should make laws and regulations in enhancing the supervision of the external audit, and reinforcing the punishment on illegal disclosure. The professional ethics education of auditors should be enhanced. And the legal protection for external investors should be strengthened.

Third, auditors should make fully use of financial information and non-financial information when assessing the risk of material misstatement in client's annual report. Auditors should also take the potential impact of the maturity mismatch on managerial behaviors and corporate financial disclosure into consideration in order to assess audit risks more precisely.

This research has several limits. First, there are limitations in the estimation of risk premiums. Both agency costs and risk premiums are directly unobservable and difficult to measure. Future research can refine the measurement of these estimates. Second, caution should be exercised in interpreting our results. Many factors should be considered in the risk assessment of auditors besides agency costs and liquidity risks of the client. The audit risk premium is the result of many risk factors. This research does not control liquidity risk or other risks. Future research can investigate the impact of SFLI on other risks and the impact of the relationship between SFLI and corporate risks on audit pricing.

\section{References}

Abbott, L. J., Gunny, K., \& Pollard, T. (2017). The impact of litigation risk on auditor pricing behavior: evidence from reverse mergers. Contemporary Accounting Research, 34(2), 1103-1127. https://doi.org/10.1111/1911-3846.12300

Abbott, L., Parker, S., Peters, G., \& Rama, D. V. (2003). Audit, non-audit and information technology fees: some empirical evidence. Accounting and the Public Interest, 3(1), 1-20. https://doi.org/10.2308/api.2003.3.1.1
Acharya, V. V., Gale, D., \& Yorulmazer, T. (2011). Rollover risk and market freezes. The Journal of Finance, 66(4), 1177-1209. https://doi.org/10.1111/j.1540-6261.2011.01669.x

Almeida, H., Campello, M., Laranjeira, B., \& Weisbenner, S. (2012). Corporate debt maturity and the real effects of the 2007 credit crisis. Critical Finance Review, 1, 3-58. https://doi. org/10.1561/104.00000001

Asthana, S. C., \& Kalelkar, R. (2014). Effect of client reputation on audit fees at the office level: an examination of S\&P index membership. Auditing: A Journal of Practice \& Theory, 33(1), 1-27. https://doi.org/10.2308/ajpt-50572

Baimukhamedova, A., Baimukhamedova, G., \& Luchaninova, A. (2017). Financial disclosure and the cost of equity capital: the empirical test of the largest listed companies of Kazakhstan. Journal of Asian Finance, Economics and Business, 4(3), 5-17. http://dx.doi.org/10.13106/jafeb.2017.vol4.no3.5

Bates, T., Kahle, K., \& Stulz, R. (2009). Why do US firms hold so much more cash than they used to? The Journal of Finance, 64(5), 1985-2021. https://doi.org/10.1111/j.15406261.2009.01492.x

Campello, M., Giambona, E., Graham, J. R., \& Harvey, C. R. (2011). Liquidity management and corporate investment during a financial crisis. Review of Financial Studies, 24(6), 19441979. https://doi.org/10.1093/rfs/hhq131

Chae, S. J., Nakano, M., \& Fujitani, R. (2020). Financial reporting opacity, audit quality and crash risk: evidence from Japan. Journal of Asian Finance, Economics and Business, 7(1), 9-17. https://doi.org/10.13106/jafeb.2020.vol7.no1.9

Choi, J. H., Kim, C. F., Kim, J. B., \& Zang, Y. (2010). Audit office size, audit quality, and audit pricing. Auditing: $A$ Journal of Practice and Theory, 29(1), 73-97. DOI: 10.2308/ aud.2010.29.1.73

Custódio, C., Ferreira, M. A., \& Laureano, L. (2013). Why are US firms using more short-term debt? Journal of Financial Economics, 108(1), 182-212. DOI:10.1016/j. jfineco.2012.10.009

Dechow, P., Sloan, R., \& Sweeney, A. (1995). Detecting earnings management. The Accounting Review, 70(2), 193-225.

Denis, D. J., \& Sibilkov, V. (2010). Financial constraints, investment, and the value of cash holdings. The Review of Financial Studies, 23(1), 247-269. https://doi.org/10.1093/rfs/ hhp031

Faccio, M. (2006). Politically connected firms. American Economic Review, 96(1), 369-386. DOI: 10.1257/000282806776157704

Fama, E., \& French, K. (2001). Disappearing dividends: changing firm characteristics or lower propensity to pay? Journal of Financial Economics, 60(1), 3-43. https://doi.org/10.1016/ S0304-405X(01)00038-1

Fama, E., \& French, K. (2004). New lists: fundamentals and survival rates. Journal of Financial Economics, 73(2), 229269. https://doi.org/10.1016/j.jfineco.2003.04.001 
Flannery, M. J. (1986). Asymmetric information and risky debt maturity choice. The Journal of Finance, 41(1), 19-37. https:// doi.org/10.1111/j.1540-6261.1986.tb04489.x

Francis, J. R. (1984). The effect of audit firm size on audit prices: a study of the Australian market. Journal of Accounting and Economics, 6(2), 133-151. DOI: 10.1016/0165-4101(84)90010-7

Goswami, G. (2000). Asset maturity, debt covenants, and debt maturity choice. The Financial Review, 35(4), 51-68. https:// doi.org/10.1111/j.1540-6288.2000.tb01429.x

Higgs, J. L., \& Skantz, T. R. (2006). Audit and non-audit fees and the market's reaction to earnings announcements. Auditing: A Journal of Practice and Theory, 25(1), 1-26. https://doi. org/10.2308/aud.2006.25.1.1

Ho, T. S. Y., \& Singer, R. F. (1982). Bond indenture provisions and the risk of corporate debt. Journal of Financial Economics, 10(4), 375-406. https://doi.org/10.1016/0304-405X(82)90017-4

Jensen, M. C. (1986). Agency cost of free cash flow, corporate finance and takeovers. American Economic Review, 76(2), 323329. DOI: $10.2139 / \mathrm{ssrn} .99580$

Jensen, M. C., \& Meckling, W. H. (1976). Theory of the firm: managerial behavior, agency costs and ownership structure. Journal of Financial Economics, 3(4), 305-360. DOI: 10.1016/0304-405X(76)90026-X

Jones, J. (1991). Earnings management during import relief investigations. Journal of Accounting Research, 29(2), 193228. DOI: $10.2307 / 2491047$

Khwaja, A. I., \& Mian, A. (2005). Do lenders favor politically connected firms? Rent provision in an emerging financial market. The Quarterly Journal of Economics, 120(4), 13711411. https://doi.org/10.1162/003355305775097524

Ladd, H. F. (1998). Evidence on discrimination in mortgage lending. Journal of Economic Perspectives, 12(2), 41-62. DOI: 10.1257/jep.12.2.41
Loury, G. C. (1998). Discrimination in the post-civil rights era: beyond market interactions. The Journal of Economic Perspectives, 12(2), 117-126. DOI: 10.1257/jep.12.2.117

Morris, J. R. (1976). On corporate debt maturity strategies. The Journal of Finance, 31(1), 29-37. DOI: 10.1111/j.15406261.1976.tb03193.x

Mukhibad, H., Subowo, S., Maharin, D. O., \& Mukhtar, S. (2020). Determinants of debt policy for public companies in Indonesia. Journal of Asian Finance, Economics and Business, 7(6), 2937. https://doi.org/10.13106/jafeb.2020.vol7.no6.029

Myers, S. C. (1977). The determinants of corporate borrowing. Journal of Financial Economics, 5(2), 147-175. DOI: 10.1016/0304-405X(77)90015-0

Ng, P. P. H., \& Tai, B. Y. K. (1994). An empirical examination of the determinants of audit delay in Hong Kong. The British Accounting Review, 26(1), 43-59. DOI: 10.1006/ bare.1994.1005

Nguyen, D. D., \& Nguyen, A. H. (2020). The impact of cash flow statement on lending decision of commercial banks: evidence from Vietnam. Journal of Asian Finance, Economics and Business, 7(6), 85-93. https://doi.org/10.13106/jafeb.2020. vol7.no6.085

Richardson, S. (2006). Over-investment of free cash flow. Review of Accounting Studies, 11(2), 159-189. https://doi.org/10.1007/ s11142-006-9012-1

Seetharaman, A., Gul, F. A., \& Lynn, S. G. (2002). Litigation risk and audit fees: evidence from UK firms cross-listed on US markets. Journal of Accounting and Economics, 33(1), 91-115. https://doi.org/10.1016/S0165-4101(01)00046-5

Simunic, D. A. (1980). The pricing of audit services: theory and evidence. Journal of Accounting Research, 18(1), 161-190. DOI: $10.2307 / 2490397$ 